\section{Dorota Stadnicka}

Associate Professor Rzeszow University of Technology Faculty of Mechanical Engineering and Aeronautics Poland

Paweł Litwin

Assistant Professor Rzeszow University of Technology Faculty of Mechanical Engineering and Aeronautics

Poland

\section{Dario Antonelli}

Professor

Politecnico di Torino, Department of Production Systems and Economics

\title{
Human Factor in Industry of the Future - Knowledge Acquisition and Motivation
}

Industry of the future bases on people knowledge, creativeness and motivations. Although, the number of workers needed in factories of the future decreases, the requiremenets concerning employees skills have been increasing. The knowledge of employees determines the factory system quality and efficiency. The motivation of people determines continuous improvement and development realized by problems identification and elimination. Hence, adequate learning methods are required to be implemented to achieve the following goals: empower and motivate people. This paper presents chosen methods such as learning by doing, computer simulations and virtual reality which support knowledge acquisition by people being prepared for work in factories of the future. The presented methods also increase employee awareness concerning possibilities of improvements.

Keywords: Industry of the future, Human factor, Learning by doing, Simulations, Virtual reality.

\section{INTRODUCTION}

Industry of the future (IoF) concerns factories organized in line with Industry 4.0 concept, called also "fourth Industrial Revolution". It is connected with Intelligent Manufacturing Systems (IMSs) in which humans and production machines interacts each other. The goal is to create a smart factory that is characterized by high level of processes digitalization and Cyber Physical Systems (CPSs) implementation. Information and communication technologies (ICT) support processes realized in smart factories. IMS requires application of innovative technologies that allow to create smart interconnected systems between smart objects [1].

IMS can be built with the support of such technologies as Clouds, Big Data, additive manufacturing, collaborative robotics. They are already implemented in different industrial contexts but still require further research to be on such stage of development that ensures full exploitation of potential which these technologies can bring.

One of the most important issues in IMS is human factor. Human resources have to be prepared to undertake their role in IMS. In IMS a high level of knowledge as well as fast knowledge adjustment to new circumstances is required from people. However, the proper training of employees is neglected. That causes problems in IMS implementation, since IMS requires close interactions between human operators and machines. If employees are not adequately prepared to work in the new production environment the technological innovations cannot be implemented with success and cannot be

Received: November 2018, Accepted: June 2019 Correspondence to: Dorota Stadnicka, PhD DSc Eng.

Rzeszow University of Technology Faculty of Mechanical Engineering and Aeronautics, Poland dorota.stadnicka@prz.edu.pl

doi:10.5937/fmet1904823S

(C) Faculty of Mechanical Engineering, Belgrade. All rights reserved fully exploit. Hence, there is a risk that costs incurred for innovative solutions will never be refunded. The reason is that the costs of solving problems will exceed the possible benefits. The whole generation of people has to switch to new solutions in a short time, since nowadays the innovations development is very fast. Therefore, also employees have to be prepared for new tasks in a short time. It is because the manufacturing systems are changing radically in IMS. These are not any more small additive innovations but huge radical improvements that change the way of management of the whole factory. In these circumstances new rules have to be implemented and new skills are required from employees. Therefore, it is apparent that currently used learning methods are not sufficient. Manuals and classroom lessons are effective to ensure knowledge acquisition but are not equally effective in teaching how to use the new technologies in everyday factory's work.

New educational techniques as well as motivating approaches are indispensable for potential students who already work in a factory. Factory workers are peculiar students that can be involved through remote learning, while staying on the job. Furthermore, they don't need the full knowledge about the new technologies, but they will learn how to introduce the new technologies in their work and how the technologies will influence the process efficiency and problems elimination. Additionally, survey from [2] finds that the learning process can be accelerated by applying innovative learning technologies as well as the by tools increase of students' involvement in the learning process.

Therefore, the goal of the paper is to show how modern learning tools can be applied to learn to work along with the enabling technologies in IMS and assess their application without impacting on the actual industrial process. Additionally, it can be expected that learning time as well as cognitive effort will be reduced. However, the mentioned aspects are out of the scope of this paper. 
This paper presents practical implementation of chosen educational method that ensure knowledge and motivation acquisition by students. The second part of the paper presents motivation behind the presented topic. Different forms of learning activities are deliberated. The third part of the paper introduces open educational platforms, i.e. MOOCs. Then, application of computer simulations in education is discussed. In the fifth part virtual reality (VR) and augmented reality (AR) in educational context are deliberated. Next, human-robot collaboration as an example of learning by doing is shown. The last learning means is a simulation assembly line that is used in training program. The summary of the work presents conclusions and future works.

\section{MOTIVATION}

Implementation of Industry 4.0 concept is considered as a long-term objective. Current industry is not ready for full implementation of IMS and all the enabling technologies. It is because IMS implementation is connected with high digitalization level.

Many of enabling technologies support employees' work and decision-making process even if they do not realize how many innovations are engaged. For example, RFID based system can be used to facilitate competition of goods for shipment in distribution centres [3]. In CPS operating in a company RFID can be embedded in products to track them across different manufacturing departments.

Another example concerns NFC (near-field communication) which is applied to maintenance processes. NFC-enabled mobile phones with NFC tags are used to ensure that all maintenance tasks will be realized in a predetermined time and documentation will be prepared in real-time [4].

Designing and then work in CPS can be supported with the use of simulations and VR or AR. They can be also used in learning process. Since simulations represent a real world, many rules can be better understand with the use of simulations before an employee start working on own work station. In VR an employee can perform a task similar to a real one avoiding potential real consequences in case of mistake.

By modelling the real work and then by performing simulations an employee can find the best solution to obtain the expected results of a decision. With the use of AR a kind of guide can be implemented to lead an operator through the task to be performed. The AR may be used only in training process or also in everyday work, of course with higher costs. In game a real world can be reflected and a learning by doing methodology can be implemented. Naturally, the games have limitations. Therefore, the world represented in the games is simplified. Anyway, the most important issues, that have to be learned by game participants are incorporated into the games. This way real problems are analysed in simulated environment. A positive competition, which can be provoked by the game leaders, can be an additional motivator for looking the best way to perform a task. The huge advantage of games is that employees learn while having fun [5]. Therefore, gamification is implemented with enthusiasm in industry as well as in education $[6,7]$.
Games allow to obtain technical as well as social skills. It is because in a game a participant performing predesigned tasks [8] for which he or she is responsible, might communicate or collaborate with other employees. In IoF team work will be the crucial skill because the interdisciplinary teams are going to work for achieving a common goal. High levels IMS will be maintained by a team of highly skilled experts from different areas. In many cases the collaboration between the experts is very difficult. That is because they use different technical language. Hence, playing the games with other people from different disciplines can prepare better employees for such problems.

In learning process different learning modes can be applied. Figure 1 presents a classification based on Lean typology of simulations [8] that shows how learning modes can be divided based on different criteria.

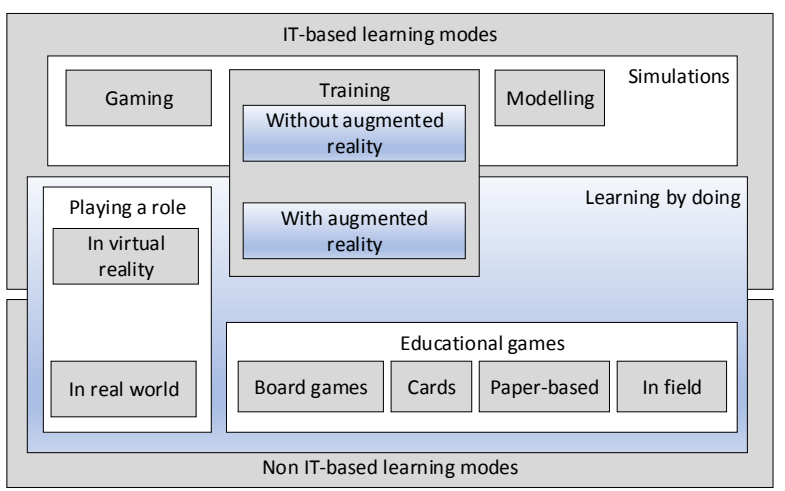

Figure 1. Classification of learning modes

This paper deals with the group of IT-based learning modes, which are divided on simulations and learning by doing. Training simulations can be performed with the use of simulators or in similar to real environment when a game participant is supported by augmented reality while performing a work. They are implemented in order to ensure that in future work an employee will have a habit of proper performing of a work. The main goal of modelling simulations is to support decisionmaking process. Learning process can be realized in VR where a trainee plays a role and have a chance for observation of own behavior consequences. The description of the learning modes can be found in [9].

Implementation of digitalization in education means that a game participant can play in the same time with other participant connecting to them in a digital world. This is the paradigm of Web 2.0. Game participants can play in a designed environment but also they can create or modify a virtual world. Additionally, they can actively participate in discussion with the use of forums, blogs or wikis not only by making a comment but also by creating the knowledge, based on own experience. This way trainees shift from passive to active role of knowledge co-creators. The new knowledge is available for all participants in a network. This motivates the participants to increase their ability of critical thinking, because the new knowledge might be not possible to be applied in all situations.

\section{OPEN EDUCATIONAL PLATFORMS (MOOC)}

The early beginnings of distance education date back to the end of the nineteenth century, when the first corres- 
pondence courses appeared. The advent of the digital age, the dissemination of information and communication technologies and easy access to the Internet led to a breakthrough in the development of distance education and the emergence of the first MOOC (Massive Open Online Courses) platform in 2008 [10]. The acronym MOOC stands for the training platform which is characterized by: unlimited number of users (Massive), available for everyone (Open) and accessible through internet (Online) courses. MOOCs are not an independent phenomenon, isolated from other developments in the field of open and distance learning. On the contrary, MOOCs are strongly associated with other achievements of education techniques, have the potential to support lifelong learning, eliminate barriers in the learning process, ensure equal opportunities in education, and most importantly enable widespread access to knowledge [11].

The MOOC platforms can be divided into two categories: $x M O O C$ and $\mathrm{cMOOC}$, which form two main pedagogical trends. $\mathrm{xMOOC}$ is dedicated to teaching in accordance with the rules of behavioral pedagogy, i.e. focused on the content and teacher [12]. The second category - xMOOC is based on a conceptual connectivist approach and has an innovative character. Connectivism is based on the assumption that the learning to think is more important than just acquiring knowledge. The creator of this theory, George Siemens [13] presents connectivism as a way of learning in the digital age. The main idea of the connectivist approach is that knowledge can be communicated via a network of links between students [14], usually with the use of social media platforms, wikis or blogs.

By definition, MOOC offers open courses, which are free for the learner. However this does not mean, that such an education platform does not generate costs for the training content provider. The creation and effective provision of high-quality training materials for thousands of users requires the involvement of experienced teachers, technical staff and a robust, scalable IT infrastructure [15]. According to the class-central report [16], the number of courses on MOOC platforms is growing every year, reaching over 11 thousands of courses in 2018. These courses are provided by over 900 universities around the world. In 2018, the number of users using MOOC exceeded 101 millions. The report [16] also provides information about MOOC platforms that support the largest number of users (in millions of registered students): Coursera (37), edX (18), XuetangX (14), Udacity (10), FutureLearn (8.7). The great popularity of MOOC platforms can also be evidenced by the information on the number of participants of individual courses. According to the report [17], the number of students in the three most popular courses exceeded 3.2 million.

In this context, one should ask the question what part of the huge number of courses offered on MOOC platforms is related to the industry of the future? The largest of the MOOC services - Coursera currently offers $(05 / 02 / 2019) 24$ courses related to the industry 4.0 keyword. Topics in this set of courses include: Digital manufacturing and design, CAD and digital manufacturing, Business models, Business strategy but also English for Science, Technology, Engineering, and Mathematics and Dairy production and management. The second largest service edX currently offers 19 courses related to industry 4.0, including 12 in the field of engineering. The third largest English-language service Udacity after typping industry 4.0 in the search field, shows an information, that it does not currently provide courses related to this subject. It is possible that after the modification of the phrase entered into the search engine more courses related to industry 4.0 would be found, but it would be difficult to give the reason for the lack of industry 4.0 in the set of keywords of such courses.

Bearing in mind the summary of the overall number of courses offered on MOOC platforms with the number of courses related to industry 4.0 and, on the other hand the growing popularity of the industry 4.0 concept clearly shows the need for increasing the presence of industry 4.0 in the MOOC space.

\section{COMPUTER SIMULATIONS IN EDUCATION}

Simulation can be defined as the operating model of the selected system [18] that enables the presentation of selected aspects of the reality [19]. The most important simulation features include: representation of real systems; the ability to change simulation scenarios; low costs of simulation experiments and protection against the consequences of serious errors.

By computer scientists, simulation is seen as the third (next to theory and experiment) way of practicing science $[20,21]$. Simulation methods in science allow for suggesting the theory, mapping of real processes, data analysis or apparatus control. After the successful implementation of simulation methods in science, at the end of the twentieth century, it was noticed that simulations may be useful also in education. This conviction is expressed in the statement [22]: "If video games can be transformed so that their users learn, a great many people may come to understand and control dynamic systems". Today, after more than two decades, this vision has become a reality, and learning based on computer simulation is an important tool in education. Education using simulation methods is based on the assumption that students instead of experimenting on a real system or device, build a model and examine its behavior in a simulation environment. It is worth noting that the use of simulation methods in education may contain two main tasks:

- Learning to create simulation models in order to know the techniques and possibilities of modeling;

- Analysis of systems, devices or materials on the base of simulation experiments.

In studies conducted among teachers using the nanoHUB.org portal [23], the main learning objectives were identified using simulation methods. These are: learning the role of simulation in science and engineering practice, creating characteristics of real systems and materials based on data from a simulation experiment, understanding causal relationships in a simulation model, estimating the accuracy of a simulation model, validating the results of a design task, applying computational techniques in modeling, predicting the results of the 
simulation experiment, matching the appropriate model to simulate the physical phenomenon.

The research results presented above clearly show the huge potential of simulation methods in educational applications. The presented characteristics of computer simulation make them applicable to explaining nonobvious phenomena or understanding the way complex systems work. Such complex systems appear in particular where people play an important role. Individual abilities and talents, tiredness, emotions and stress can have a significant impact on the actions and decisions of a person cooperating with the technical system. Learning using simulations allows students to build models and practice the systems and devices they will use in their future work. The use of simulation that way can avoid many mistakes with serious economic consequences and often also a threat to health and life.

\section{VIRTUAL REALITY AND AUGMENTED REALITY IN EDUCATION}

VR is everything that is not real. It allows you to experience a world that does not have a physical form. Head Mounted Display (HMD) is the current form of a hardware delivering VR experiences to users, and one of the most common VR terms you'll hear about today. An HMD is typically a pair of goggles or a helmet of some type, with which you view the VR experience.

$\mathrm{AR}$ is a technology that enhances the real world with virtual elements (computer-generated). It has three basic properties [24]: combination of real and virtual objects in the real environment; realignment of real and virtual objects; interaction working in real time.

The shift from VR to AR paradigm is seen as a continuum by [25] and not as a sequence of rigid steps (Figure 2). Milgram gives a general and technology independent definition of AR. In a broad sense, AR refers to "augmenting natural feedback to the operator with simulated cues"

With a few exceptions, the focus in AR applications is more oriented on the technology employed to insert visually credible artificial objects in a real environment than on the content visualized. This way of working is justified by the relative novelty of the technology and by the possibility to continually improve the user experience with the evolution of the AR devices. Thus it is only an answer to the question 'how AR'. The advancement in the AR supporting technology, both hardware and software, has made possible to employ commercial solutions to build AR applications.

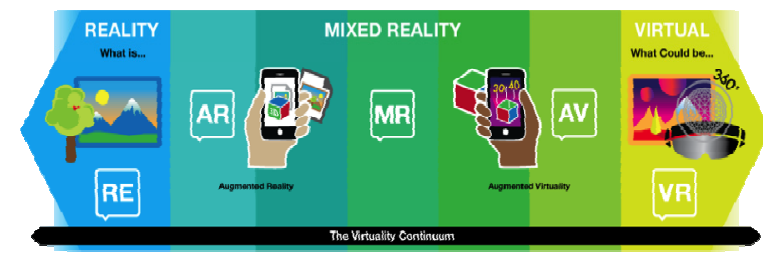

Figure 2. The Virtuality Continuum according to Milgram

There are still two open questions: 'what' to display and 'why'? In the application of AR to learning, the questions should be answered in reverse sequence: decide on the kind of assistance required by a student during the learning activity, select the information to display, chose the most appropriate AR device.

There is a rationale behind the emergence of these applications: the attention span is reduced in new generations, nevertheless the majority of them is able to engage for extended periods of time when gaming or using simulations. Researches have shown that we remember less what we hear, or what we see, while we are able to recall nearly all of what we do. AR assists the creation of a credible operating scenario for the learning of industrial tasks, with guiding instructions that overlay on the actual reality.

Constructivist learning is fitted for VR and AR as it allows students to actively practice what they are learning. Participative learning requires the simultaneous presence of a group of learners in the same place. If the place is virtual the students could be everywhere (but simultaneously the time constraint is still valid). VR has both the assets of real world classrooms and of online (distance) learning. There are significant drawbacks that could hinder a systematic application of AR to complex study subjects [26].

- AR requires more work to be implemented if compared with traditional teaching material.

- It must be acknowledged that realistic AR is not cheap and headsets are not comfortable for a long time use.

- Moreover, the different devices employed must be continuously updated and maintained without losing the integration of sensors and displays that is crucial for the realism of user experience.

- There is a cognitive effort in communicating through VR that is more than the effort required to talk face to face.

\section{LEARNING BY DOING: HUMAN-ROBOT COLLA- BORATION}

An example of learning by doing experimented in the laboratory of Politecnico di Torino, Italy, is the collaborative human-robot assembly of flanges on a base, as represented in Figure 3. The components are easy to find in every hardware store.

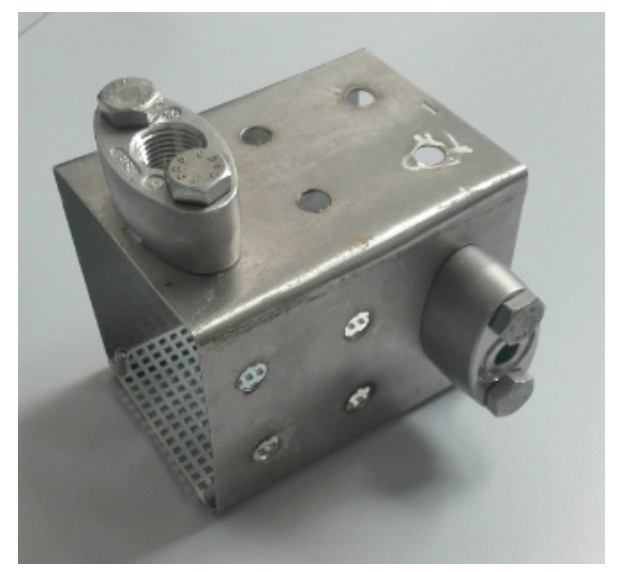

Figure 3. The sample assembly flange

The students are required to analyse the assembly task, subdivide it into several elementary operations, assign each operation respectively to a robot or to a human operator and, finally, to program the robot to execute the collaborative assembly tasks (Figure 4). 
The first task is assigned to a human operator. It consists of placing a base and flanges on the reference position. The human starts collaborative task execution by sending direction commands to perform the assembly in the prescribed horizontal or vertical direction. In the following task the robot grabs the flange, moves it to the assembly position and keeps maintaining the flange in the correct orientation and at the correct distance from the flange reference points. The task requires force and accuracy and it is best suited to the robot. The human can join the flange to the base by screwing it.

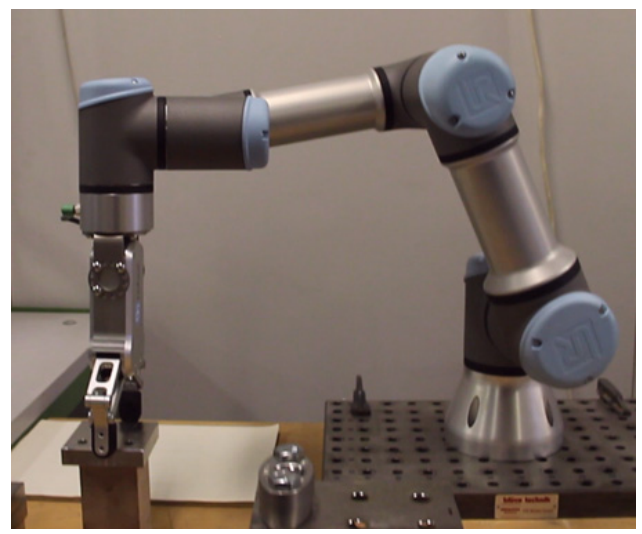

Figure 4. The collaborative robot during the assembly

The task requires high dexterity and, this time, the human appears more proficient in it. The task assignment and the robot programming are not defined a priori, leaving the student wide space of discretion. The programmed trajectories are shown as a simulated process on a monitor in front of the student that can verify the robot program before executing it in the real workspace.

What is more important, from the viewpoint of present paper, is that students were able to program the robot in a fraction of the time usually required as there is no more need to learn and memorize commands in robot language but just to learn how to program by manual guidance.

\section{COMPUTER SIMULATIONS: SIMULATION OF PROJECT RISK}

This chapter presents the simulation experiment carried out in the course of "Risk management in IT projects". This subject is carried out in the field of "Production management and engineering" and as a result of the course students acquire, among others, the ability to: identify risk factors, model and simulate risk, assess the impact of risk on the project. Modeling and simulation are methods often used to estimate the impact of risk on a project due to the lack of experience with certain risk factors in previously implemented projects.

A change in macroeconomic conditions (for example a change in the rate of inflation) during the project implementation is a risk factor that can have a significant impact on the project's result. The main goal of the task carried out in the course on "Risk management in IT projects" is to estimate the impact of the change in the rate of inflation on the implementation of the project budget, and in particular on the possibility of implementing all the activities planned in the project within the assumed budget.

The students' task is to analyze the project carried out in the Imple Masters company. The company is running a project in which 20 people are employed. The project implementation time is 24 months. The budget of the project is 10 million euros. The budget should pay employees' wages (an average of EUR 5,000 per month), pay for the operation of premises (EUR 120,000 per month) and deliveries of components (1 million in $6^{\text {th }}$ month, 1.5 million in $12^{\text {th }}$ month and 2 million in $18^{\text {th }}$ month). The costs indicated were set at the project start date - they may change as a result of inflation. Wages in the project change at a rate $1 \%$ lower than inflation rate, operating costs of premises increase by $2 \%$ above inflation rate, and delivery costs grow $1 \%$ above the inflation rate. Funds for project are stored on an interest-free bank account. The result of the simulation should be data on the budget resources used, with inflation amounting from $1 \%$ to $6 \%$.

In the first stage of the task implementation, students should develop a model of financial flows in the project. The project's funds are sent from the "Project funds" account to the "Payrol costs", "Operating costs" and "Components" accounts. Cash flows depend on fixed values (wages, costs of component purchases, costs of the operation of premises) and on the time and rate of inflation. The cash flow model in the project is illustrated in Figure 5.

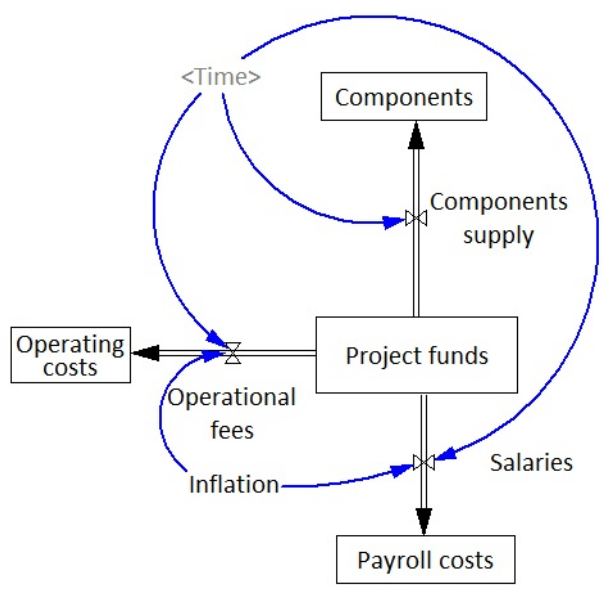

Figure 5. Cash flow model in the project

Formula (1) shows the method of calculation of monthly salaries (in thousands of euros).

Salaries $=\left(5^{\star} 20\right)^{\star}\left(1+\right.$ Time $^{*}($ Inflation-0.01)/12)

In the simulation experiment the rate of inflation is set (from $1 \%$ to $6 \%$ with a step of $1 \%$ ) and then after the simulation, the account balance of the project is checked at the end of the project. The simulation results are presented in Table 1. The results presented in Table 1 indicate that the implementation of the project within the planned budget is possible only with $1 \%$ inflation rate.

With higher inflation rates ( $2 \%$ or more) it will be necessary to involve additional funds. The simulation model also allows to specify the time in which the project's account balance will go down to zero. This example is shown in Figure 6 - budget funds for $2 \%$ 
inflation rate have been used 2 months before the end of the project.

Table 1. Simulation results; PAB - Project account balance

\begin{tabular}{|c|c|c|c|}
\hline Inflation rate & PAB & Inflation rate & PAB \\
\hline $1 \%$ & 37.2 & $4 \%$ & -264.6 \\
\hline $2 \%$ & -63.4 & $5 \%$ & -365.2 \\
\hline $3 \%$ & -164.0 & $6 \%$ & -465.8 \\
\hline
\end{tabular}

The example shown is not sophisticated, and at the same time allows for the implementation of several educational goals. Students learn the basics of modeling in the System Dynamics method (SDM), identify and describe mathematically causal relationships, conduct a simulation experiment and interpret its results.

Fifteen students developed a model and performed simulations. Then, they have been asked to assess the level of difficulty and workload. The task completion time given by students was 2.5 to 4 hours (median is 3.5 hours). The difficulty was assessed on the Likert scale (1-very easy, 2-rather easy, 3-I have no opinion, 4rather difficult, 5-very difficult). Students almost unanimously $(86 \%)$ assessed the difficulty of the task as 4 rather difficult; highlighting in comments that the difficulty comes from the first contact with the System Dynamics method and Vensim software.

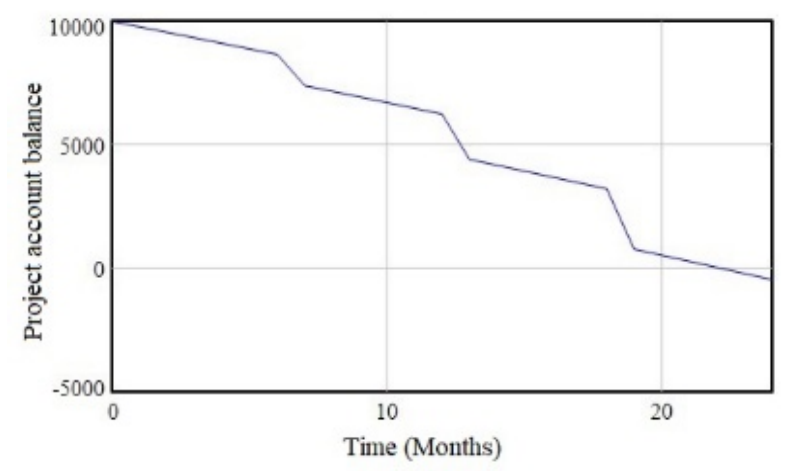

Figure 6 . The project account balance on $2 \%$ inflation rate

It should be noticed that the students had an alternative to solve the task in an Excel spreadsheet. However, Excel was used only for some students to present the simulation results obtained in Vensim. This is probably due to the necessity of using in Excel financial mathematics functions (e.g. future value of capital), which are usually not familiar to engineers.

\section{VIRTUAL REALITY: MANUFACTURING SYS- TEMS OPERATIONS IN THE VIRTUAL WORLD}

VR can be created to be a copy of the real world. An example, presented in this papers, concerns an assembly line existing in Rzeszow University of Technology, Poland [27]. The line is dedicated for education in the field of mechatronic systems [28]. The physical assembly line has own digital twin in which operations can be tested before they are applied in the reality. Additionally, the work can be realized simultaneously in VR and in the real world based on the same working program. Any discrepancies in behaviour of both systems can be easily notified. The students program the system, observe its behaviour, implement changes and assess performance looking for the best solution.

The system is composed of different elements that can play different roles in the learning process. The work [9] describes the equipment included in the system. With the use of the system the students can learn about robots collaboration problems. They can also deal with the quality issues. The recognition system (Figure 7) can easy identify a wrong part. Taking a wrong product can also cause collisions what can lead to safety problems. The problems can also arise when in a storage (Figure 8) the products are placed in wrong places or in a wrong order.

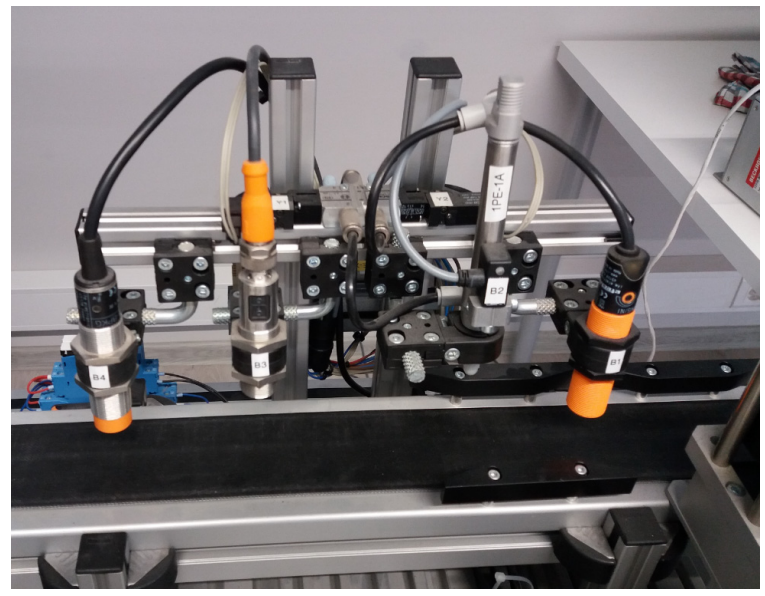

Figure 7. A recognition system in reality

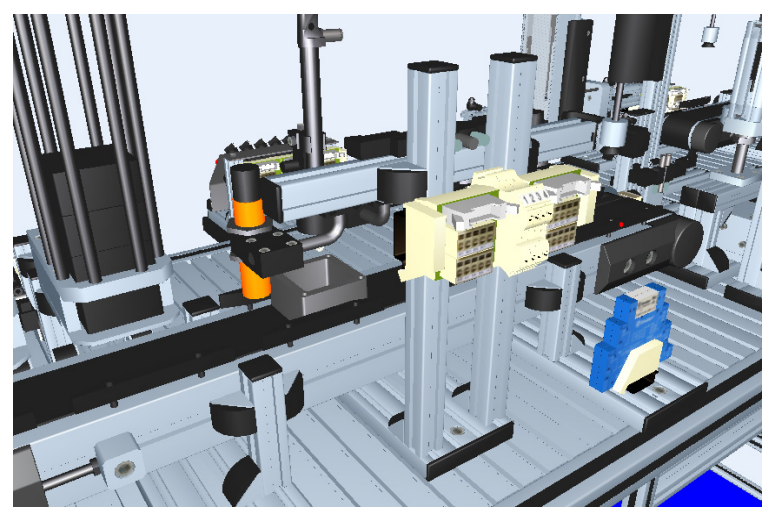

Figure 8. A recognition system in VR

The proper process parameters have to be chosen to ensure the required results of the assembly process. Transport belts are the elements of a transport system. The adequate speed has to be chosen to ensure that the products will be on time ready to be grasped by a robot. A finished product warehouse can be used to test different arrangement of the ready products taking into account clients' orders.

The learning process provides the following intended learning outcomes (ILO). After training session on the assembly line a student will:

ILO 1: Plan an assembly process based on a client requirements, schedule the manufacturing tasks in an adequate order and control the process.

ILO 2: Program the machine tools incorporated in the manufacturing line.

ILO 3: Program the cylindrical and Cartesian robots to work in collaborative environment. 
ILO 4: Program PLC controllers to ensure undisturbed work.

The expected system operation is realized in the following steps:

- With the use of a transport belt a component is transported from the input warehouse to the recognition system to check the kind of element.

- With the use of a cylindrical robot the element is transported to a preparation workstation and next to an assembly workstation.

- With the use of the same robot the second element is transported to the assembly workstation.

- With the use of a hydraulic press the elements are assembled.

- With the use of the second robot the assembled product is transported to the second transport belt.

- The third robot transfers the product to a Cartesian robot directly.

- The Cartesian robot places the product in a final warehouse.

In the line such additional elements as turning $\mathrm{CNC}$ machine ST-20 or milling CNC machine VF-2 can be included. Also, a grabber warehouse can be applied. Moreover, for workpieces manipulating a manipulation system which can be connected with the iRVision system and Fanuc M-10iA robot can be introduced. Furthermore, a Mitsubishi RV-M2 robotic assembly station can be included.

The areas in automation technology that can be incorporated in a teaching program are as follow: task sequence optimization, set-up operations, design of logic control, commissioning, automatic operations, possible problem identification and elimination, and others. Learning process includes individual and team projects. Students have to communicate to be sure that all system elements will collaborate to achieve a goal.

\section{CONCLUSIONS}

IoF requires well skilled employees who continuously improve their knowledge and skills. The development of technologies forces companies to constant changes. Therefore, the employees should be ready and motivated to understand new situation and to undertake new tasks. They also should be prepared for unknown problems and they should know tools to be used in the problems analyses and solving. Hence, the appropriate learning methods need to be introduced to provide people with readiness and motivation for different challenges. The paper presents classification of learning modes which can be used in learning process. These modes which are connected with novel IT tools are underlined and some examples of their application are discussed, presenting the usefulness in learning process of complex problems. As it was discovered in a survey, the modern tools (e.g. SDM) do not have to be time consuming and students can be willing to use them more that well known tools (such as Excel).

The companies have different possibilities and can choose the most suitable learning tools taking into account the organization context. The presented examples of practical application of the chosen methods can help the companies to make decision. Certainly, the same methods can be used in higher education to prepare future employees for upcoming challenges.

In the future work the authors are planning to apply different methods in a learning process and assess how students perceive the proposed methods and what results can be achieved with these methods.

\section{ACKNOWLEDGEMENTS}

This work has been partially supported by the "TIPHYS 4.0 - Social Network based doctoral Education on Industry 4.0", project No 2017-1-SE01-KA203-03452 funded by ERASMUS+ of the European Commission.

\section{REFERENCES}

[1] Zabinski, T.: Implementation of programmable automation controllers - promising perspective for intelligent manufacturing systems. Management and Production Engineering Review, Vol. 1, No 2, pp. 56-63, 2010.

[2] Dávideková, Monika; Mjartan, Michal; Greguš, Michal. Utilization of virtual reality in education of employees in Slovakia. Procedia computer science, 2017, 113: 253-260.

[3] Leung, K. H., Choy, K. L., Tam, M. C., Lam, C. H. Y., Lee, C. K. H., Cheng, S. W. Y.: A hybrid RFID case-based system for handling air cargo storage location assignment operations in distribution centers, 2015 Portland International Conference on Management of Engineering and Technology (PICMET), Portland, OR, 2015, pp. 1859-1868, 2015.

[4] Karpischek, S. et al.: A Maintenance System Based on Near Field Communication," 2009 Third International Conference on Next Generation Mobile Applications, Services and Technologies, Cardiff, Wales, pp. 234-238, 2009.

[5] Lucardie, D.: The Impact of Fun and Enjoyment on Adult's Learning, Procedia - Social and Behavioral Sciences, Vol. 142, pp. 439-446, 2014.

[6] Riedel, J. C. K. H., Hauge, J. B.: State of the art of serious games for business and industry, 2011 17th International Conference on Concurrent Enterprising, Aachen, pp. 1-8, 2011.

[7] Oliveira, M., Cerinsek, G., Duin, H., Taisch, M.: Serious Gaming in Manufacturing Education. In: Ma M., Oliveira M.F., Petersen S., Hauge J.B. (eds) Serious Games Development and Applications. SGDA 2013. Lecture Notes in Computer Science, Vol. 8101. Springer, Berlin, Heidelberg, 2013.

[8] Lean, J., Moizer, J., Towler, M., Abbey, C.: Simulations and games: use and barriers in higher education. Active Learning in Higher Education., Vol. 7, No 3, pp. 227-242, 2006.

[9] Stadnicka D., Litwin P., Antonelli D.: Human factor in intelligent manufacturing systems knowledge acquisition and motivation. Procedia CIRP, Vol. 79, pp. 718-723, 2019.

[10]Downes, S.: Connectivism and connective knowledge: Essays on meaning and learning networks, National Research Council Canada, http://www. 
downes.ca/files/books/Connective_Knowledge19May2012.pdf, retrieved 7.01.2019.

[11]Zawacki-Richter, O. et al.: What Research Says About MOOCs - An Explorative Content Analysis, The International Review of Research in Open and Distributed Learning, S.1, Vol. 19, No 1, http://www.irrodl.org/index.php/irrodl/article/view/ 3356/4490, retrieved 7.01.2019.

[12] Chen, Y.: Investigating MOOCs Through Blog Mining, International Review of Research in Open and Distance Learning, Vol. 15, No 2, pp. 85-106, 2014, http://www.irrodl.org/index.php/irrodl/ article/view/1695, retrieved 8.01.2019.

[13] Siemens, G.: Connectivism: A learning theory for the digital age, 2014, http://er.dut.ac.za/bitstream/handle/123456789/69/S iemens_2005_Connectivism_A_learning_theory_fo r_the_digital_age.pdf, retrieved 8.01.2019.

[14] Rogers, P. C.et al.: A Web 2.0 learning platform: Harnessing collective intelligence. The Turkish Online Journal of Distance Education (TOJDE), Vol. 8, No 3, 2007.

[15] Meinel, C., Totschnig, M., Willems, C.: OpenHPI: Evolution of a MOOC platform from LMS to SOA. 5th International Conference on Computer Supported Education, CSEDU, Aachen, 2013.

[16] Dhaval, S.: By The Numbers: MOOCS in 2018, https://www.class-central.com/report/mooc-stats2018/, retrieved 8.01.2019.

[17] OnlineCourseReport: THE 50 MOST POPULAR MOOCS OF ALL TIME An Online Course Report RANKING, 2017, https:/www.onlinecoursereport .com/the-50-most-popular-moocs-of-all-time/, retrieved 7.01.2019.

[18] Greenblat, C. S.: Basic concepts and linkages. In C. S. Greenblat\&R.D. Duke (Eds.), Principles and practices of gaming-simulation. Beverly Hills, CA: Sage, pp. 19-24, 1981.

[19] Crookall, D, Saunders, D.: Towards an integration of communication and simulation. In D. Crookall \& D. Saunders (Eds.), Communication and simulation: From two fields to one theme. Clevedon, UK: Multilingual Matters, pp. 3-29, 1989.

[20] Kleiber, M.: Modeling and computer simulation fashion or the natural development trend of science (in Polish), Science, Vol. 4, pp. 29-41, 1999.

[21] Axelrod, R.: Advancing the Art of Simulation in Social Science. W: R. Conte, R. Hegselmann, P. Terna (red.), Simulating Social Phenomena, Berlin: Springer, pp. 21-40, 1997.

[22] Simons, K. L.: New technologies in simulation games. Systems Dynamics Review, Vol. 9, pp. 135152, 1993.
[23] Magana, A.J., Brophy, S.P., Bodner, G.M.: Instructors' intended learning outcomes for using computational simulations as learning tools. J. Eng. Educ. 101(2), 220-243 (2012)

[24] Azuma, R., Baillot, Y., Behringer, R., Feiner, S., Julier, S., MacIntyre, B.: Recent advances in augmented reality. Computer Graphics and Applications, IEEE, 21(6), pp. 34-47, 2001.

[25] Milgram, P., Takemura, H., Utsumi, A., Kishino, F.: Augmented reality: a class of displays on the reality-virtuality continuum. Proceedings the SPIE: Telemanipulator and Telepresence Technologies, Vol. 2351, pp. 282-292, 1994.

[26] Wu, H. K., Lee, S. W. Y., Chang, H. Y., Liang, J. C.: Current status, opportunities and challenges of augmented reality in education. Computers \& Education, Vol. 62, pp. 41-49, 2013.

[27] The Modular Mechatronic System from Rexroth. Rexroth Bosh Group. Retrived from: http://pdf.directindustry.com/pdf/rineer/ mechatronics/ 9037-693840.html, 2018.04.30.

[28]Kluz, R, Ciecińska, B.: The possibility of simulating the course of production processes in a modular mechatronic system (in Polish). Technologia i Automatyzacja Montażu, Vol. 3, pp. 62-66, 2012.

\section{ЉУДСКИ ФАКТОР У ИНДУСТРИЈИ БУДУЋНОСТИ - СТИЦАҢЕ ЗНАҢА И МОТИВАЦИЈА}

\section{Д. Стадницка, П. Литвин, Д. Антонели}

Индустрија будућности заснива се на знању, креативности и мотивацији људи. Иако се број потребних радника у фабрикама у будућности смањује, захтеви везани за вјештине запослених су у порасту. Знање запослених одређује квалитет и ефикасност фабричког система.

Мотивација људи одређује континуирано усавршавање и развој који се остварују идентификацијом и елиминацијом проблема. Због тога су потребне адекватне методе учења да би се постигли следећи циљеви: дати људима одговорност и мотивисати их. Овај рад представља изабране методе као што су учење кроз рад, рачунарске симулације и виртуална стварност које подржавају стицање знања оних који се припремају за рад у фабрикама будућности. Представљене методе такође повећавају свест запослених о могућностима побољшања. 